\title{
Research Article: Assessment of bio fertilizer through farmers participatory approach for integrated nutrient management in marigold
}

\author{
D.K. Mishra, Nitin Pachlaniya, A.K. Shukla and Alok Deshwal
}

Article Chronicle : Received :

02.12.2017;

Revised :

12.01.2018;

Accepted :

27.01.2018

KeY WoRdS :

Marigold, On farm

trial, Bio fertilizer

SUMMARY : Marigold has earned tremendous popularity as floral crop in Madhya Pradesh particularly at Indore district where it is being commercially cultivated as loose flower at around 2300 hectare in open field condition. With the objectives to address the problem of low yield with poor quality flower of marigold leading to lower economic returns, an assessment of integrated nutrient management with bio fertilizer application in marigold under open field condition was attempted during year 2015-16 and 2016-17 by Krishi Vigyan Kendra, Kasturbagram consisting 10 innovative farmers with three treatment, including farmers practice $T_{1}$ (NPK @ 60-90-32 kg/hac), recommended practice $T_{2}$ ( NPK $200 \mathrm{~kg}-100 \mathrm{~kg}$ $-80+20$ tonnes FYM/ha) and modified recommended practice $\mathrm{T}_{3}$ (NPK @ $150 \mathrm{~kg}-100 \mathrm{~kg}-80 \mathrm{~kg}+$ Azotobacter and PSB @ 5kg/Hac +20 tonnes FYM/ha ). Out of three treatment, flower yield under the modified recommended practice $(105.1 \mathrm{q} / \mathrm{ha})$ was significantly higher than recommended practice $(99.23$ q/ha) followed by farmers practice ( $86.40 \mathrm{q} / \mathrm{ha}$ ). Similarly gross income (Rs. 157650.00), net return (Rs. 96156.00) and BC ratio (2.56) under modified recommended practice were also recorded significantly higher over recommended practice $\left(\mathrm{T}_{2}\right)$ and farmers practice $\left(\mathrm{T}_{1}\right)$. Flower diameter in terms of centimetre was recorded highest $(3.39 \mathrm{~cm})$ under refinement $\left(\mathrm{T}_{2}\right)$ followed by recommended $\left(\mathrm{T}_{2}\right) 3.06 \mathrm{~cm}$ and farmer's practice $\left(\mathrm{T}_{1}\right) 2.45 \mathrm{~cm}$.

How to cite this article : Mishra, D.K., Pachlaniya, Nitin, Shukla, A.K. and Deshwal, Alok (2018). Assessment of bio fertilizer through farmers participatory approach for integrated nutrient management in marigold. Agric. Update, 13(1): 111-113; DOI : 10.15740/HAS/AU/13.1/111-113.

Author for correspondence :

\section{D.K. Mishra}

Krishi Vigyan Kendra,

Kasturbagram, Indore

(M.P.) India

Email:dkmishra.indore@

gmail.com

See end of the article for

authors' affiliations 